\title{
NOTES
}

1 Specimen Days, in Prose Works 1892, ed. Floyd Stovall (New York: New York University Press, 1963), 1:150-152.

2 Madeleine B. Stern, Heads $\mathcal{E}$ Headlines: The Phrenological Fowlers (Norman: University of Oklahoma Press, 1971), pp. 115-117. The Life Illustrated sketches are collected in New York Dissected, ed. Emory Holloway and Ralph Adimari (New York: Rufus Rockwell Wilson, 1936).

3 Thoreau and Alcott stayed at the Institute when they came to visit Whitman in the autumn of 1856. Alcott, who lectured there, praised its display of "the best models of the Human Body, exhibiting its organs and functions in health, also diseased." See The Letters of Bronson Alcott, ed. Richard L. Herrnstedt (Ames: Iowa State University Press, 1963), p. 207 and pp. 200-207, passim; The Fournals of Bronson Alcott, ed. Odell Shepard (Boston: Little, Brown and Co., 1938), pp. 286-291.

4 Harold Aspiz, Walt Whitman and the Body Beautiful (Urbana and London: University of Illinois Press, 1980), pp. 44-45, 257.

5 Trall decried tenement dwellings and made a plea for fresh air in his Sexual Physiology (New York: Wood and Holbrook, 1871), p. 252. In 1877 Whitman remarked on the irony that Americans "leading a free natural open-air life should, directly they make a little money, want to go in for sofas, expensively furnished rooms, dress, and such like; yet it seems to be a kind of law, a kind of necessity that they should do so." See Edward Carpenter, Days with Walt Whitman (New York: Macmillan, 1896), p. 23.

\section{WHITMAN'S DARK SEA: A NOTE ON "PATROLING BARNEGAT"}

Although nineteen years of life remained to Walt Whitman after his paralytic stroke in 1873, his poetic output was significantly diminished during those years; and of the poems he wrote, only a few stand out as being of consequence, equal to all but the very best of his earlier achievements. Perhaps the last of these notable poems is "Patroling Barnegat," published in 1880. It is a remarkable work that deserves to be better known.

"Patroling Barnegat" describes a fierce winter storm as viewed from the shores of Barnegat Bay, New Jersey; the time is around midnight, and in the darkness a few people stand in a group, looking out at the turbulent sea. Whitman may actually have seen the storm he describes, but that is unlikely; in 1880 he was in no condition to be standing out on the beach in violent winter weather, at nighttime, and there is no indication in his writings that he did any such thing. It is more probable that the poem finds its origins in an earlier storm mentioned in the Specimen Days entry for 4 June 1880 . In this passage Whitman recalls a few moments among his "rare and blessed bits of hours, reminiscent, past - the wild sea storm I once saw one winter day, off Fire Island. . . ." It is unlikely that in June of 1880, when "Patroling Barnegat" was published, Whitman would be remembering so vividly a storm off Fire Island had he more recently witnessed one so impressive as that in his poem. The reason for moving the location to Barnegat Bay would be to increase the sense 
of dramatic immediacy by placing the storm near Whitman's residence of the time, so as to suggest that he might actually have been there. It would also appear that Whitman changed the time of the storm he remembered from day to night in order to make the scene more ominous and threatening. Clearly it is important that the poem be set in darkness.

On a first reading of "Patroling Barnegat" one notices immediately its uncharacteristic formal techniques; indeed, for a poem so much concerned with nature's wildness, this work is surprisingly contrived in composition. It is fourteen lines long, the length of a sonnet, and each line ends with a present participle. While Whitman had used such repetition before (see "Out of the Cradle Endlessly Rocking," lines 130-142), it is a risky device. At first the effect may seem overdone; we come to expect the participle, to wait in anticipation of it. The cumulative force is unremitting; but that is just what Whitman wants. In the unbroken wave of participles we sense something of the storm's relentless force, its terrible energy; the words pound in like surf, tireless and inexhaustible.

The effect is enhanced by internal patterns of verbal repetition. Key words and phrases recur: "roar," "milk-white combs careering," "slush and sand," "midnight." These words, it should be noted, cover (1) sound, (2) water, (3) wind, (4) land, (5) time, (6) sky, and (7) darkness; all the major elements are emphasized. In addition to these repetitions, "steady" comes back as "steadily," "watchful" as "watching," and "savagest trinity" as "savage trinity." Like the participles, these resonant words intensify our sense of the storm's repetitive powers; the scene forces itself on our minds, allowing no respite. Our awareness of inescapable power is further heightened by the lack of a finite verb (outside a one-line parenthetical insertion): time seems to be suspended as the storm has its way. Thus the unusually prominent verbal devices of "Patroling Barnegat" serve to give strong emphasis to Whitman's depiction of violent and uncontrollable nature.

This depiction is also unusual, especially when we consider the date of the poem. Not all poets achieve serenity in their old age, but Whitman did, and his later poems, quiet, calm, and meditative, reflect it. They do not rage against the dying of the light; the universe seems to be in order right to the end, and Whitman looks upon the nature of things with tranquil acceptance. "Patroling Barnegat," however, presents a rather different picture. The storm in this poem sharply outlines the insignificance of human beings against the great energies of nature, for it reduces the people on the shore to "A group of dim, weird forms, struggling, the night confronting, / That savage trinity warily watching." The "savage trinity" is the water, the wind, and the darkness of night; vicious and threatening, these are forces of furious power, beyond all control, frenzied and strange. It is not a voice that the poet hears in the wind, as Job did, but "demoniac laughter." That is the storm's message to mankind.

In its way, "Patroling Barnegat" presents a stark emblem of the human situation. The people in the poem look out at the vast dark powers of a universe they cannot understand, a universe that seems to have gone insane. It is wildly destructive ("That in the distance! is that a wreck? is the red signal flaring?") and lacking in any morality visible to humans. If it is not actively evil (the phrase "savage trinity" suggests a demoniac parody of the Christian Trinity), it is surely intimidating, and there are no signs that it is at all beneficent or well-disposed to mankind. At the 
very least, what the poem gives us is an image of raw power, inaccessible to human reason and unresponsive to human needs or desires.

What is particularly striking in this poem is the enervated state of the people in it. They are essentially passive, "warily watching" rather than acting, merely "confronting" the night that bears down upon them. This is what humans must do, the poem suggests. Those on the shore are not defiant in their posture, and they certainly do not celebrate the great force of nature, as the earlier Whitman might have done; they are perceived only as "dim, weird, forms," huddled against the universe, waiting to give what aid they can to those in distress (though if that is a shipwreck there seems to be little they can do to help). It is endurance that characterizes them, not action or defiance. They must submit to the nature of things; that is what it means to be human.

At certain points "Patroling Barnegat" is comparable to Wordsworth's extraordinary poem of reconsideration, "Elegiac Stanzas," a work in which Wordsworth responds to his brother's drowning at sea in 1805 by revising his philosophic stance in order to take account of nature's unpredictable violence and hostility; significantly, a central section of Wordsworth's poem describes, as "Patroling Barnegat" does, a storm at sea, with a ship in distress-a "pageantry of fear," Wordsworth calls the scene. Whitman might well have used the same phrase to describe the situation in "Patroling Barnegat," for humanity in this poem is seen as exposed and vulnerable, precariously poised against the vast natural forces that threaten destruction. If the poem is a vision of old age, it is by no means a comforting one, for it suggests that in the last analysis we are alone and helpless in a hostile universe. We can keep watch, and that may help for a time, but sooner or later we are beaten down, and that is the end of it.

"Patroling Barnegat" is, especially for Whitman, an unusually dark poem. There is nothing in it capable of redeeming the time, nothing of joy or love or human magnificence, nothing of hope or consolation. All the energy belongs to the storm; by contrast, the humans are weak and pitiful. There have, of course, always been moments of darkness in Whitman's poems, right from the start; but with only rare exceptions the darkness has always been overcome or transcended. In "Patroling Barnegat" it is unrelieved. To say this, however, is not to claim that the poem represents some radical and lasting change of attitude, for Whitman was never one to dwell long in the heart of darkness. What "Patroling Barnegat" illustrates is a lesser assertion, that Whitman's range of mood and sensibility is surprisingly wide, much wider than is generally thought. Along with the celebration in his work there is profound knowledge of human frailty and defeat; the one accents and authenticates the other. It is important to know, and to state insistently, that Whitman's affimations came not from ignorance or naiveté, but from the depths of experience, for only the affirmations that are earned can command respect. Whitman knew what the world could do, and in "Patroling Barnegat" he presents an emblem of his knowledge; but he also knew of other possibilities, and they may be found in the rest of his poetry. 